\title{
Поверхностные плазмонные волны в гибридных фотодетекторах Ge/Si с металлическими субволновыми решетками
}

\author{
А.И. Якимов \\ Институт физики полупроводников им. А.В.Ржанова СО РАН, \\ Новосибирск, 630090, пр. Ак. Лаврентьева, 13 \\ тел:+7 (383) 333-2832, факс:+7 (383) 333-2832, эл.nочта: yakimov@isp.nsc.ru
}

DOI 10.34077/RCSP2019-60

Созданы гибридные ИК фотодетекторы на основе гетероструктур $\mathrm{Ge} / \mathrm{Si}$ с квантовыми точками $\mathrm{Ge}$, сопряженные с субволновыми золотыми решетками. Двумерные периодические решетки отверстий в золотых пленках с диаметром отверстий от 0.7 до 1.0 мкм и периодом 1.1-2.0 мкм выступали в качестве метаповерхностей, позволяющих преобразовать внешнее электромагнитное излучение в поверхностные плазмон-поляритонные волны в спектральном диапазоне 3-5 мкм. Из зависимостей фототока от угла падения электромагнитной волны определены дисперсионные соотношения, характеризующие распространение поверхностных плазмонных мод вдоль границы металлполупроводник в плазмонных фотодетекторах $\mathrm{Ge} / \mathrm{Si}$ с квантовыми точками $\mathrm{Ge}$, совмещенные с регулярными золотыми решетками субволновых отверстий различной формы на поверхности полупроводника. Было показано, что экспериментальные дисперсионные кривые для решеток круглой и квадратной формы находятся в хорошем согласии с результатами численного моделирования дисперсионных характеристик фундаментального плазмонного резонанса. Полученные результаты свидетельствуют о том, что усиление фототока в гибридных фотодетекторах с квантовыми точками действительно вызвано возбуждением блоховских поверхностных плазмонных мод в среднем ИК диапазоне. Обнаружено подавление эффекта плазмонного усиления фототока при переходе от круглой и квадратной форм отверстий решетки к прямоугольной. Установлено, что в гибридных структурах с прямоугольными щелями существует диапазон волновых векторов, в котором энергия поверхностных плазмонов не зависит от волнового вектора падающего излучения. Полученные результаты объяснены возбуждением световой волной локализованных дипольных мод на прямоугольных апертурах с большим соотношением сторон. Методами математического моделирования и экспериментально исследованы процессы усиления поля световой волны и фототока в среднем ИК диапазоне в гибридных гетероструктурах $\mathrm{Ge} / \mathrm{Si}$ c квантовыми точками $\mathrm{Ge}$, содержащих два типа плазмонных метаповерхностей на кремнии. Один тип представлял собой периодические решетки отверстий в золотой пленке, второй - двумерные массивы наноантенн в виде золотых дисков. Показано, что решетки отверстий обеспечивают усиление ближнеполевых компонент в активной области детекторов в 2.3-2.9 раз больше по сравнению с массивами дисковых антенн. Больший коэффициент усиления электрического поля связан с большей глубиной проникновения вглубь полупроводника поверхностной плазмонной волны, возбужденной перфорированной металлической пленкой. В результате возбуждения поверхностных плазмонных волн в оптимальных гетероструктурах $\mathrm{Ge} / \mathrm{Si}$ с квантовыми точками удалось получить квантовую эффективность на уровне $2 \%$, токовую чувствительность до $0.4 \mathrm{~A} /$ Вт и фотовольтаическую обнаружительную способность $4.5 \times 10^{12} \mathrm{cм} \cdot \Gamma_{ц}^{1 / 2} /$ Вт на длине волны 4 мкм при $T=78 \mathrm{~K}$.

Исследования проведены при финансовой поддержке гранта РФФИ №16-29-03024. 